\title{
Antigenic evolution of SARS-CoV-2 in immunocompromised hosts
}

$5{ }^{3}$ Department of Mathematics, Simon Fraser University, Burnaby, BC, V5A 1S6, Canada.

$6 \quad *$ Corresponding author. Email: benashbyevo@ gmail.com 


\section{Abstract}

The apparent lack of antigenic evolution by the Delta variant (B.1.617.2) of SARS-CoV-2 during the

11 COVID-19 pandemic is puzzling. The combination of increasing immune pressure due to the rollout

12 of vaccines and a relatively high number of infections following the relaxation of non-pharmaceutical

13 interventions should have created perfect conditions for immune escape variants to evolve from the

14 Delta lineage. Instead, the Omicron variant (B.1.1.529), which is hypothesised to have evolved in an immunocompromised individual, is the first major variant to exhibit significant immune escape following vaccination programmes and is set to become globally dominant in 2022 . Here, we use a simple mathematical model to explore possible reasons why the Delta lineage did not exhibit antigenic evolution and to understand how and when immunocompromised individuals affect the emergence of immune escape variants. We show that when the pathogen does not have to cross a fitness valley for immune escape to occur, immunocompromised individuals have no qualitative effect on antigenic evolution (although they may accelerate immune escape if within-host evolutionary dynamics are faster in immunocompromised individuals). But if a fitness valley exists between immune escape variants at the between-host level, then persistent infections of immunocompromised individuals allow mutations to accumulate, therefore facilitating rather than simply speeding up antigenic evolution. Our results suggest that better global health equality, including improving access to vaccines and treatments for individuals who are immunocompromised

27 (especially in lower- and middle-income countries), may be crucial to preventing the emergence of 28 future immune escape variants of SARS-CoV-2.

\section{Lay Summary}

We study the role that immunocompromised individuals may play in the evolution of novel variants 


\section{Introduction}

35 Understanding how and when variants of SARS-CoV-2, the causative agent of COVID-19, are likely to

36 evolve is key to managing the future of the pandemic. Multiple variants of concern have evolved

37 since the start of the pandemic, with higher transmissibility evolving on at least two occasions, by

the Alpha (B.1.1.7) variant (relative to the wildtype) [1], and by the Delta (B.1.617.2) variant (relative

to Alpha) [2,3], with the latter becoming the globally dominant strain in 2021 [4]. Other variants

such as Beta (B.1.351) and Omicron (B.1.1.529) have instead shown evidence of immune escape,

51 hypothesis using a simple mathematical model to understand the potential importance of

52 immunocompromised individuals for the antigenic evolution of SARS-CoV-2.

54 A fundamental tenet of evolutionary epidemiology is that the rate of antigenic evolution depends on a balance between immune pressure and mutation supply [11-13]. The greater the proportion of the population that is immune, the greater the strength of selection for immune escape but

57 mutation supply is constrained as few hosts can be infected. Conversely, if many hosts are 
relatively weak. Hence, the rate of antigenic evolution should be maximised at an intermediate level strong.

Rapid deployment of vaccinations against SARS-CoV-2 combined with the relaxation of nonpharmaceutical interventions in many countries led to both strong immune pressure and high numbers of infections in the latter half of 2021. For example, by the end of November 2021 the UK had fully vaccinated $68 \%$ of the population while still experiencing over 620 confirmed cases per million (approximately 70\% of the previous peak in January 2021) [14]. At the time, the Delta variant was dominant globally and accounted for over $99 \%$ of infections in the UK [14]. Yet, despite apparently favourable evolutionary conditions for immune escape there were no indications of the Delta variant exhibiting antigenic evolution in the UK or elsewhere. Instead, the Omicron variant, first detected in South Africa and reported to the World Health Organization on November 24, 2021 [9], was able to substantially escape host immunity and evolved from a different clade. Omicron contains 30 mutations to the spike protein (used for binding to host cell receptors) and has been shown to evade over $85 \%$ of neutralizing antibodies [7]. Relative to Delta, Omicron exhibits substantially lower vaccine effectiveness [15] and is estimated to be over five times as likely to lead to reinfection [6]. Omicron became the dominant variant in the UK within a month and is on course to replace Delta in many countries in early 2022 [14]. but also that selection for immune escape towards the end of 2021 was very strong. According to the conceptual model of antigenic evolution as a balance between immune pressure and mutation 
medRxiv preprint doi: https://doi.org/10.1101/2022.01.13.22269154; this version posted January 13, 2022. The copyright holder for this preprint (which was not certified by peer review) is the author/funder, who has granted medRxiv a license to display the preprint in perpetuity.

It is made available under a CC-BY-ND 4.0 International license .

84 was simply due to insufficient mutation supply. However, this is difficult to reconcile with the high

85 number of cases at the time, implying mutation supply was plentiful. Furthermore, if mutation

supply was the key constraint, how did an immune escape variant appear from an obscure clade that was responsible for few infections?

89 A promising hypothesis is that the Omicron variant arose due to long-term within-host evolution in

90 an immunocompromised individual, who was most likely infected between March and August 2021

91 [9]. While an immunocompetent individual would be expected to clear infection after a relatively

92 short period, an immunocompromised person may fail to fully clear the infection, allowing the virus

93 to coevolve with the immune system [16]. Indeed, longitudinal sequencing from an

94 immunocompromised patient who was infected for over 150 days with SARS-CoV-2 revealed rapid

95 accumulation of mutations [17]. These mutations appeared to be adaptive at the within-host level

96 due to their concentration in the spike protein, with several common to other variants of concern.

97 Similar results have been observed in other patients with long-term infections of SARS-CoV-2

$98[18,19]$, including those who have been treated with convalescent plasma, indicating antigenic 99 evolution within the host [20].

It is currently unclear how important immunocompromised individuals are for the antigenic evolution of SARS-CoV-2. Do infections of immunocompromised individuals simply accelerate 103 antigenic evolution or do they play a key role in facilitating immune escape? In the first case, 104 infection of immunocompromised individuals speeds up antigenic evolution due to faster within105 host dynamics, leading to the emergence of new immune escape variants on shorter timescales than 106 would be possible in an immunocompetent population. Such a scenario would suggest that although 107 immunocompromised individuals might speed up the process, they are not essential for antigenic 108 evolution to occur. In the second case, long-term infections of immunocompromised individuals 
medRxiv preprint doi: https://doi.org/10.1101/2022.01.13.22269154; this version posted January 13, 2022. The copyright holder for this preprint (which was not certified by peer review) is the author/funder, who has granted medRxiv a license to display the preprint in perpetuity.

It is made available under a CC-BY-ND 4.0 International license .

allow the virus to accumulate mutations that are advantageous at the within-host level but may be disadvantageous at the between-host level. If there is epistasis between mutations at the between host level (i.e. fitness depends on the context of which other mutations are present), then sustained adaptation within immunocompromised individuals may allow the virus to traverse valleys in the fitness landscape, which would otherwise be very difficult to cross, to reach another peak (Fig. 1b).

The second scenario would therefore suggest that long-term infections in immunocompromised individuals play a crucial role in the antigenic evolution of SARS-CoV-2.

Here, we analyse a simple phenomenological model to explore the potential importance of immunocompromised hosts for the antigenic evolution of SARS-CoV-2. We show that in the absence of epistasis, antigenic evolution readily occurs regardless of the frequency of immunocompromised individuals in the population. If epistasis is present, however, such that the virus must traverse a fitness valley at the between-host level to escape host immunity, then immunocompromised hosts are crucial for antigenic evolution to occur. These patterns are robust irrespective of whether withinhost evolutionary dynamics are faster in immunocompromised individuals and for a wide range of parameters affecting cross-immunity, the strength of epistasis, the proportion of the population that is immunocompromised and their duration of infection relative to immunocompetent hosts.

\section{Model description}

We adapt the model of antigenic evolution presented by Gog and Grenfell [21] to incorporate immunocompromised individuals and epistasis. The model assumes that there are $n=30$ variants equally spaced in a line, with adjacent variants differing by a single mutation. Hosts are classed as either entirely susceptible to a variant, or entirely immune to it. Cross-immunity between variants is therefore 'polarising', which means that when an individual is infected by variant $i$, a proportion $\sigma_{i j}$ 
133 of those currently susceptible to variant $j$ become fully immune to it for life (no waning immunity)

134 and a proportion $1-\sigma_{i j}$ remain fully susceptible to variant $j$. This assumption greatly reduces the 135 complexity of the model as it means we do not need to track all infection histories, which would 136 require at least $(2+n) 2^{n} \approx 137$ billion classes with $n=30$. The strength of cross-immunity 137 between variants $i$ and $j$ is given by

$$
\sigma_{i j}=\exp \left\{-\frac{(i-j)^{2}}{2 \eta}\right\}
$$

138 where $\eta>0$ controls the breadth of cross-immunity (large values of $\eta$ give broad cross-immunity between distant variants, whereas small values of $\eta$ limit cross-immunity to closely related variants;

140 Fig. 1a). We assume that the population is large, well-mixed, and of constant size $\left(N=10^{7}\right)$, with a proportion $p$ of individuals who are immunocompromised (only able to produce a weak immune response; subscript $C$ ) and a proportion $1-p$ who are immunocompetent (able to produce a normal or "healthy" immune response; subscript $H$ ). For simplicity, we ignore host demographics

144 (births and deaths) and mortality from infection, as we are only interested in the antigenic evolution 145 of the virus over a relatively short timescale. 
(a)

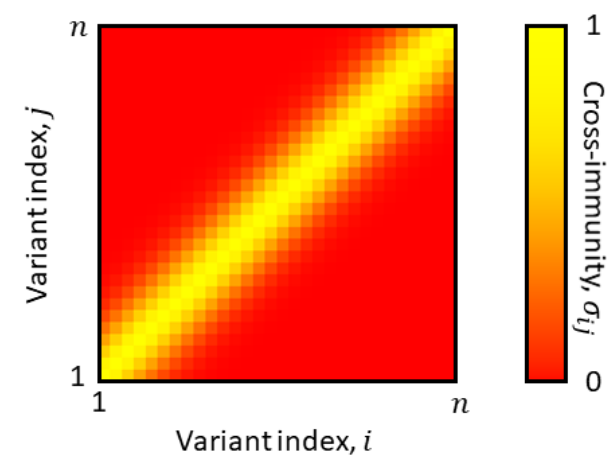

(b)

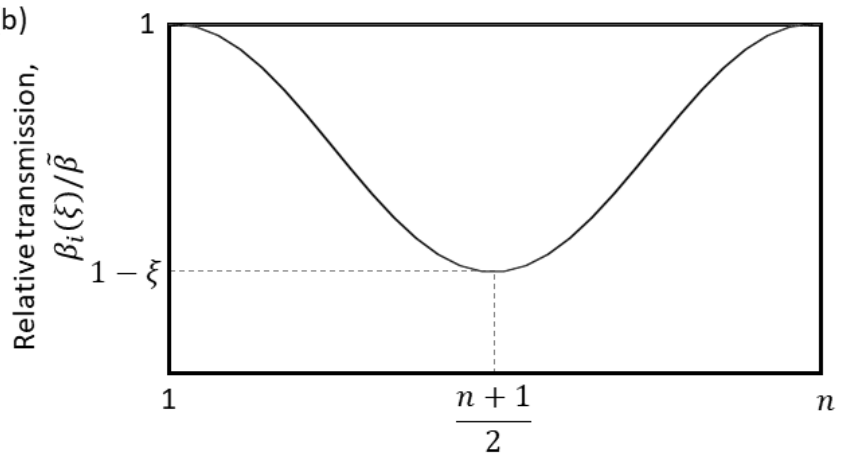

(c)
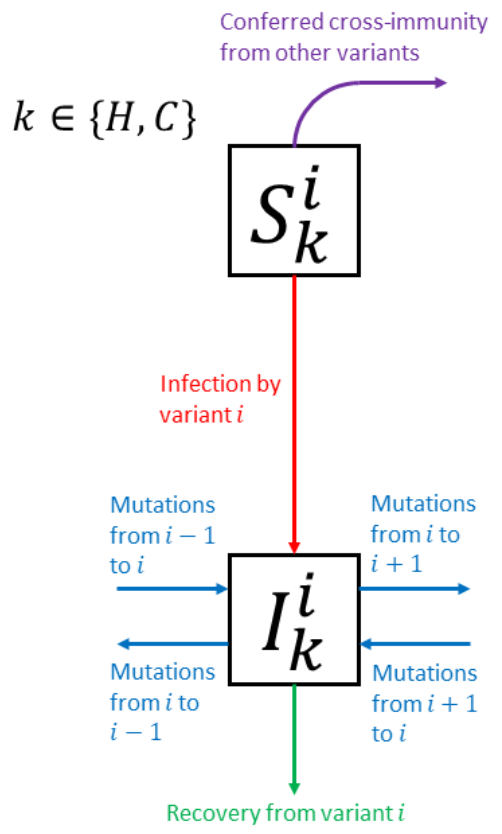

Figure 1: Population-level model. (a) Cross-immunity, $\sigma_{i j}$, for variants $i$ and $j$, with lighter colours corresponding to greater

Let $S_{H}^{i}$ (respectively $S_{C}^{i}$ ) be the proportion of the population that is immunocompetent (resp. immunocompromised) and susceptible to variant $i \in\{1, \ldots, n\}$, and $I_{H}^{i}$ (resp. $I_{C}^{i}$ ) be the proportion of the population that is immunocompetent (resp. immunocompromised) and infected with variant $i$.

153 To incorporate a fitness valley at the between-host level, we assume that the transmission rate of variant $i$ is given by

$$
\beta_{i}(\xi)=\tilde{\beta}\left(1+\frac{\xi}{2}\left(\cos \left(\frac{2 \pi(i-1)}{n-1}\right)-1\right)\right),
$$

where $\tilde{\beta}$ is the maximum transmission rate and $\xi$ controls the strength of epistasis (Fig. 1b). produce results consistent with those presented below. When $\xi=0$, there is no epistasis as $\beta_{i}(\xi)=\tilde{\beta}$ for all variants. When $0<\xi<1$, epistasis reduces the transmission rate for variants 
163 for the underlying ordinary differential equations (ODEs)

$$
\begin{gathered}
\frac{d S_{k}^{i}}{d t}=-\sum_{j=1}^{n} \beta_{j}(\xi) S_{k}^{i} \sigma_{i j}\left(I_{H}^{j}+I_{C}^{j}\right), \\
\frac{d I_{k}^{i}}{d t}=\beta_{i}(\xi) S_{k}^{i}\left(I_{H}^{i}+I_{C}^{i}\right)-\left(\gamma_{k}+\frac{\mu_{k}}{1+\delta_{i}}\right) I_{k}^{i}+\frac{1}{2} \mu_{k} M_{k}^{i},
\end{gathered}
$$

where $M_{k}^{i}$ is the set of variants adjacent to $i$ in the one-dimensional antigenic space $\left(M_{k}^{i}=I_{k}^{i-1}+\right.$

$I_{k}^{i+1}$ for $i \in\{2, \ldots, n-1\}$, with boundary conditions $M_{k}^{1}=I_{k}^{2}$ and $\left.M_{k}^{n}=I_{k}^{n-1}\right)$, and $\delta_{i}=1$ if

$i \in\{1, n\}$ and is 0 otherwise to control the rate of antigenic evolution at the boundaries. A schematic for this system can be found in Fig. 1c.

We run 10 simulations for each parameter combination up to $t_{\max }=1460$ time steps (days), as preliminary analysis revealed that either antigenic evolution reaches the boundary of antigenic space within this timeframe, or the infection is driven extinct. Note however, that this duration is arbitrary and varies inversely with $\mu_{C}$ and $\mu_{H}$. We say that a variant is 'observed' if it exceeds a threshold of 0.01 . In each simulation, we summarise the dynamics by measuring the total number of variants observed and the maximum distance in antigenic space between observed variants. 
medRxiv preprint doi: https://doi.org/10.1101/2022.01.13.22269154; this version posted January 13, 2022. The copyright holder for this preprint (which was not certified by peer review) is the author/funder, who has granted medRxiv a license to display the preprint in perpetuity.

It is made available under a CC-BY-ND 4.0 International license .

\section{Results}

177 We focus our analysis on the strength of epistasis on transmissibility , the strength of cross178 immunity, the proportion of the population that is immunocompromised, the relative rate of 179 adaptation in immunocompromised hosts . In the absence of epistasis (or when epistasis is sufficiently weak), the virus diffuses gradually through antigenic space (Figs. 2a and 2c). As the host population accumulates immunity to the current dominant variant, selection favours the next variant in line that can substantially escape immunity, leading to successive epidemic waves at regular intervals. This occurs regardless of whether within-host evolution is assumed to be faster in immunocompromised individuals (Fig. 3a).
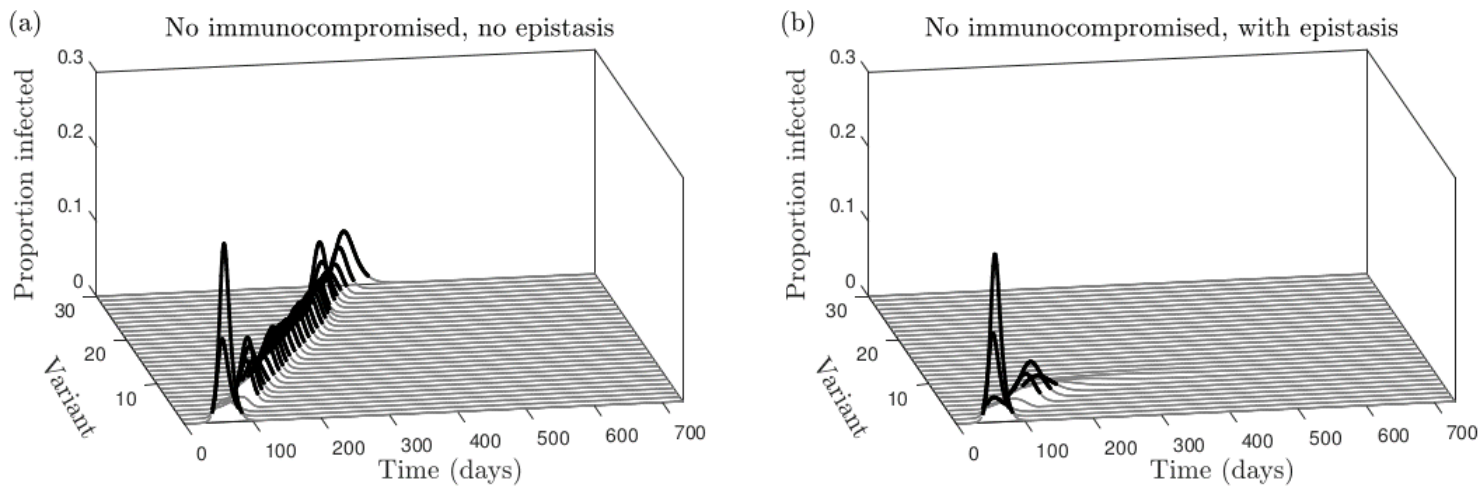

(c) With immunocompromised, no epistasis
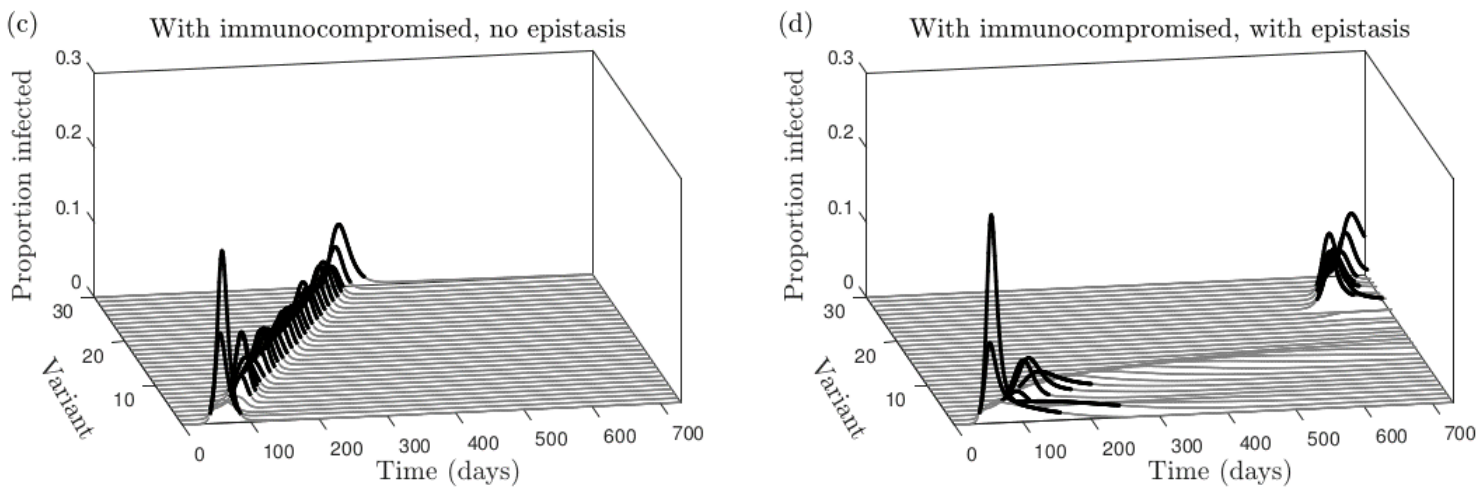

Figure 2: Antigenic evolution with or without immunocompromised individuals and epistasis. (a) No epistasis in an

(b) Strong epistasis in an entirely immunocompetent population 
medRxiv preprint doi: https://doi.org/10.1101/2022.01.13.22269154; this version posted January 13, 2022. The copyright holder for this preprint (which was not certified by peer review) is the author/funder, who has granted medRxiv a license to display the preprint in perpetuity.

It is made available under a CC-BY-ND 4.0 International license .

191 When epistasis is sufficiently strong, however, the proportion of the population that is

192 immunocompromised plays a crucial role in antigenic evolution (Figs. $2 b$ and $2 d$ ). If very few

193 individuals are immunocompromised, the epidemic quickly burns out with little antigenic evolution,

194 as the virus is unable to cross the fitness valley caused by epistasis at the between-host level (Fig.

195 2b). But if a sufficient proportion of the population is immunocompromised, then the virus can cross

196 this fitness valley due to within-host evolution in this subpopulation (Fig. 2d). Immunocompromised

197 hosts experience longer infections, on average, which allows the virus to gradually accumulate

198 mutations and cross the fitness valley. When the virus has acquired enough mutations in the

199 immunocompromised such that between-host fitness is restored, it is able to spread in the rest of

200 the host population. Again, this process is sped up if the within-host evolutionary dynamics are

201 assumed to be faster in immunocompromised individuals, but the qualitative dynamics are

202 unchanged (Fig. 3b).

203
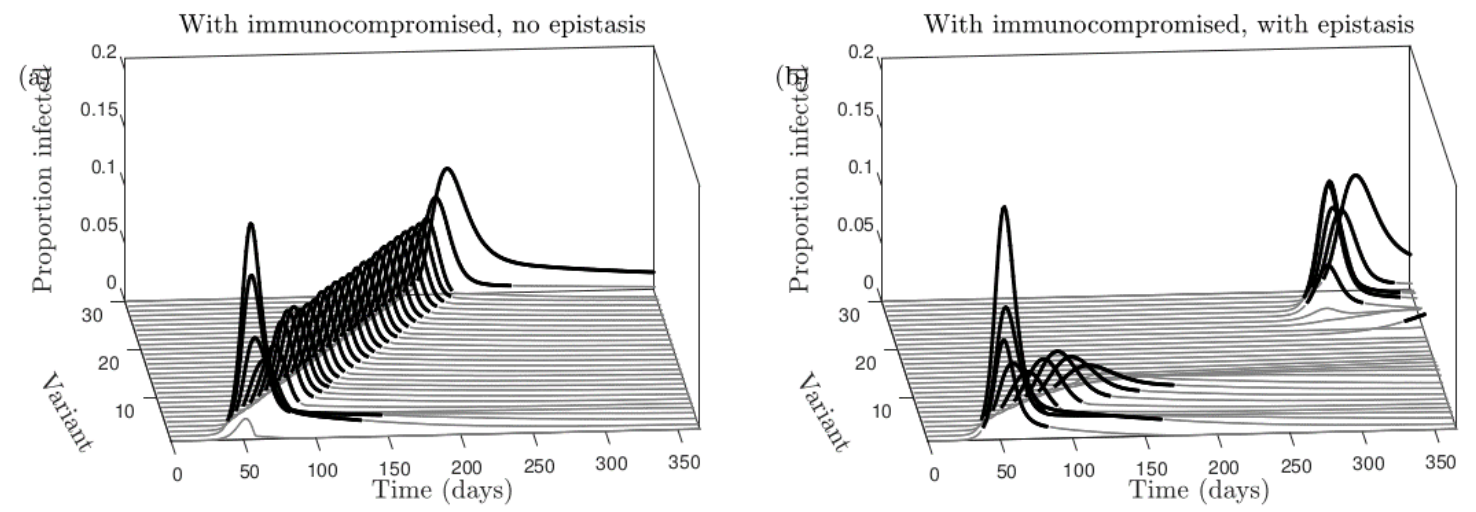

Figure 3: Antigenic evolution when the rate of within-host evolution is faster in immunocompromised individuals. In both

plots, there is a small immunocompromised proportion

and the rate of within-host evolution in the

Our results are robust to variation in key model parameters, although our sensitivity analysis reveals

210 immunity between variants, we find that, intuitively, immunocompromised individuals are especially

211 important for traversing the fitness valley if epistasis is stronger or if cross-immunity is broader 
medRxiv preprint doi: https://doi.org/10.1101/2022.01.13.22269154; this version posted January 13, 2022. The copyright holder for this preprint (which was not certified by peer review) is the author/funder, who has granted medRxiv a license to display the preprint in perpetuity.

It is made available under a CC-BY-ND 4.0 International license .

212 (Figure 4a). This is because stronger epistasis makes the fitness valley deeper and broader cross-

213 immunity reduces the pool of susceptible hosts across a wider range of variants. However, if

214 epistasis is sufficiently strong (around $\xi=0.9$ in Figure 4a) a large jump in antigenic space to a

215 distant variant occurs regardless of the strength of cross-immunity. Our sensitivity analysis also

216 reveals that as the proportion of the population that is immunocompromised decreases, a jump in

217 antigenic space becomes less likely and requires a longer relative infectious period in

218 immunocompromised hosts (Figure 4b). This suggests that better treatment of

219 immunocompromised hosts (to reduce the average duration of infection) and better prevention and

220 treatment of pre-existing conditions (to reduce the proportion of the population that is

221 immunocompromised) may greatly reduce the likelihood of new variants emerging at distant fitness

222 peaks

(a)

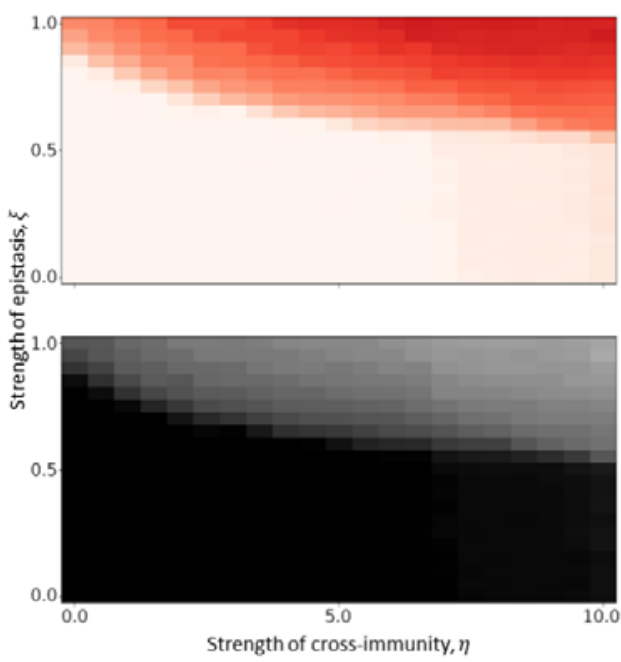

223

224

225 A3. All datapoints are averaged over 10 simulations. (b)

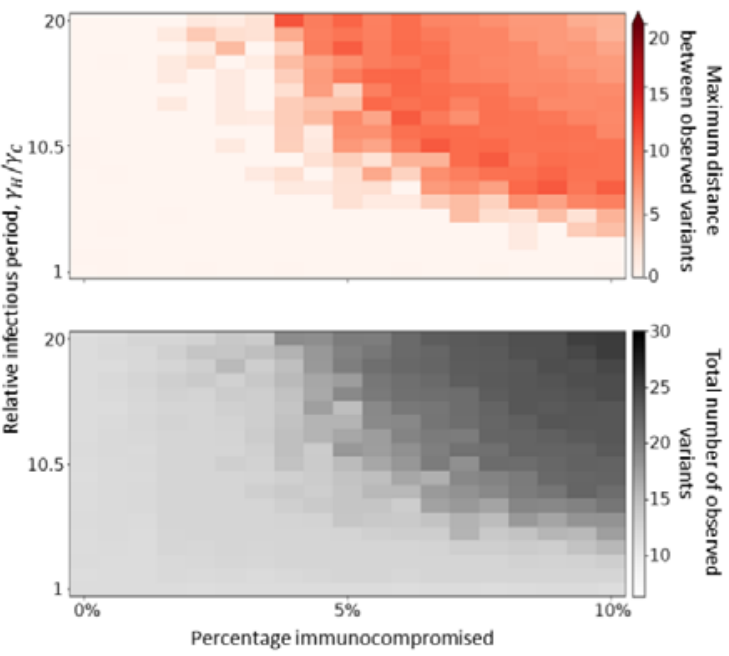

Figure 4: Sensitivity analysis. Top row: maximum distance between observed variants (darker shading indicates larger jumps in antigenic space); bottom row: total number of variants observed. (a) Varying the strength of cross-immunity ( $\eta$ ) and epistasis $(\xi)$ when $5 \%$ of the population is immunocompromised ( $p=0.05)$. (b) Varying the percentage of the population that is immunocompromised and the relative recovery periods (with $\eta=5$ and $\xi=0.8$ ). All other parameters as in Table 
medRxiv preprint doi: https://doi.org/10.1101/2022.01.13.22269154; this version posted January 13, 2022. The copyright holder for this preprint (which was not certified by peer review) is the author/funder, who has granted medRxiv a license to display the preprint in perpetuity.

It is made available under a CC-BY-ND 4.0 International license .

\section{Discussion}

231 The presence of immunocompromised individuals has been suggested as an important driver behind

232 not only the emergence of the Omicron variant, but also other variants of concern, including Alpha

233 and Delta [17]. Using a simple model of antigenic evolution, we have shown that prolonged

234 infections of immunocompromised individuals allow pathogens to accumulate sufficient mutations

235 to overcome epistasis at the between-host level, facilitating the emergence of novel immune escape

236 variants. Our model was motivated by the surprising lack of antigenic evolution arising from the

237 Delta lineage in 2021. Given relatively high levels of infection (and hence mutation supply) combined

238 with rapidly increasing immune pressure in mid- to late-2021, conditions for the Delta lineage to

239 exhibit antigenic evolution seemed to be favourable. The local mutational space appears to have

240 been thoroughly explored by the Delta variant (Fig. 5), which suggests that mutation supply was not

241 the fundamental constraint for the lack of antigenic evolution. Indeed, our model suggests that

242 novel immune escape variants readily evolve when epistasis is relatively weak. When epistasis is

243 stronger, reducing transmissibility for variants between fitness peaks, we find that

244 immunocompromised individuals play a key role in antigenic evolution, effectively allowing the

245 pathogen to traverse the fitness valley to reach a new peak. Note that while faster within-host

246 adaptation in immunocompromised individuals speeds up the rate of antigenic evolution, unlike

247 epistasis it does not qualitatively affect the outcome. Crucially, we have also shown that improving

248 treatment for those who are immunocompromised can greatly reduce the likelihood of new variants

249 emerging. 


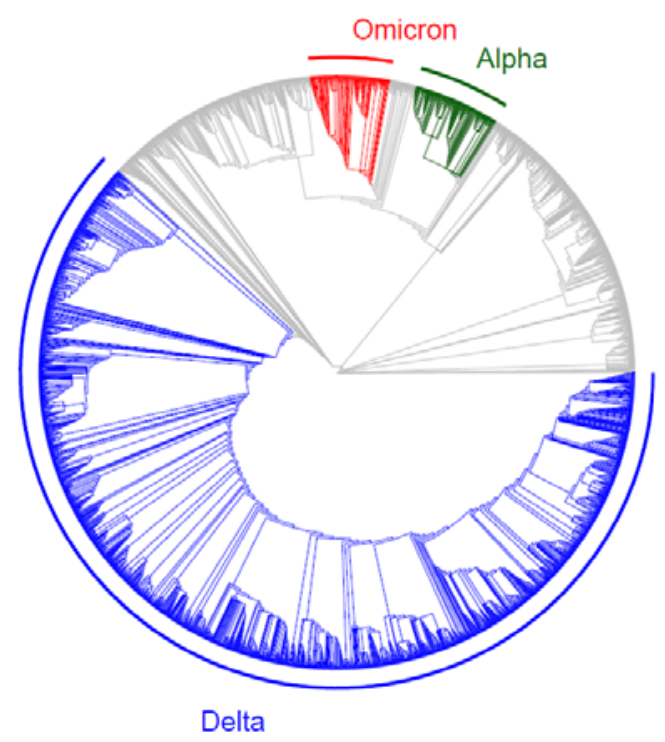

Figure 5: Phylogenetic tree for SARS-CoV-2 variants. Three variants of concern (Alpha, Delta and Omicron) are highlighted

to illustrate that there has been high mutation supply for the Delta variant. Data downloaded from Nextstrain

253 (nextstrain.org) [23,24] and provided by the Global Initia tive for Sharing All Influenza Data (GISAID, gisaid.org) [25-27].

255 While our model does not capture the full complexity of antigenic evolution, it has important 256 implications for our understanding of future immune escape variants of SARS-Cov-2. Crucially, our model suggests that the lack of antigenic evolution by Delta followed by the emergence of Omicron is consistent with epistasis constraining immune escape, but epistasis may be overcome when immunocompromised individuals are infected for sufficiently long periods. Hence, rather than simply accelerating antigenic evolution, prolonged infections of immunocompromised individuals may be critical for the evolution of immune escape variants. Based on the lack of antigenic evolution by Delta, we tentatively speculate that it may be difficult for SARS-CoV-2 to evolve antigenically

263 through incremental mutations, and future variants may require multiple (epistatic) mutations to substantially escape host immunity. If true, a possible implication is that vaccines against SARS-CoV-

2652 may not need to be regularly updated in a similar manner to seasonal influenza vaccines, but if new variants do emerge, they may substantially escape prior immunity and be harder to predict. 
medRxiv preprint doi: https://doi.org/10.1101/2022.01.13.22269154; this version posted January 13, 2022. The copyright holder for this preprint (which was not certified by peer review) is the author/funder, who has granted medRxiv a license to display the preprint in perpetuity.

It is made available under a CC-BY-ND 4.0 International license .

267 However, it is also possible that Delta was unusual in being limited in its scope for antigenic evolution and that other variants may not experience similar constraints in the fitness landscape.

Our results agree with previous models which suggest that immunocompromised individuals are more likely to facilitate or accelerate within-host pathogen evolution, for example due to a longer

272 average duration of infection or higher viral load [31,32]. However, while we find

273 immunocompromised hosts to play a crucial role in pathogen evolution at the population level,

274 other studies have concluded the opposite as these individuals only make up a small proportion of

275 infections [31,32]. The reason for this discrepancy is likely due to contrasting assumptions regarding

276 within-host fitness, immunity, and traits under selection. For example, van Egeren et al. [32] assume

277 that a fitness valley exists at the within-host level with two or three mutations required to cross,

278 whereas our model assumes that the fitness valley only exists at the between-host level

279 (transmission) but may require many more mutations to traverse. If a fitness valley exists at the within-host level, then intuitively the importance of immunocompromised individuals for pathogen evolution will be lower. Their model also focused on a static measure of relative fitness and did not consider antigenic evolution explicitly, whereas in our model the fitness of a particular variant depends on the level of immunity in the population, and so will vary over the course of the epidemic. Nevertheless, both models concur that longer duration infections, especially those of immunocompromised individuals, can play a disproportionate role in the evolution of novel variants, and are of particular concern for SARS-CoV-2 evolution.

We assumed that the rate of antigenic evolution during an infection was constant (but may vary by host type), which was motivated by the within-host model discussed in the appendix. For

290 immunocompetent hosts, who typically clear infection within two weeks [33], this means that there 291 is relatively little time for new variants to emerge for onwards transmission, which slows down 
medRxiv preprint doi: https://doi.org/10.1101/2022.01.13.22269154; this version posted January 13, 2022. The copyright holder for this preprint (which was not certified by peer review) is the author/funder, who has granted medRxiv a license to display the preprint in perpetuity.

It is made available under a CC-BY-ND 4.0 International license .

adaptation and can prevent epistatic mutations accumulating. But for immunocompromised hosts, who may experience much longer infections (upwards of 150 days [17]), the coevolutionary dynamics between the virus and the host immune system could allow many (potentially epistatic) mutations to accumulate. Interestingly, this hypothesis is consistent with previous theoretical [34] and experimental [35-37] studies showing that coevolution can both accelerate adaptation and allow a pathogen to cross fitness valleys caused by epistasis.

In this study we have focused on evolution in immunocompromised individuals as a source of immune escape variants such as Omicron, but two alternative explanations must also be considered [10]. The first is that Omicron evolved early in the pandemic in a remote population (e.g., in southern Africa) before eventually taking off globally in late 2021 . However, the combination of a large number of mutations in the spike protein and strong selection for immune escape in the wider population renders this explanation unsatisfactory, as it does not explain why these mutations did not appear in places where mutation supply and immune pressure were both high, such as the UK in late 2021. The second is that Omicron evolved in an animal host following transmission from humans, before crossing the species barrier into humans once again. This is a plausible but requires crossing the species barrier twice and selection to favour mutations that are beneficial in both the animal species and humans. We believe it is more plausible that Omicron evolved in an immunocompromised individual, especially since this is consistent with longitudinal sequencing of within-host evolution $[17,18]$.

We stress that while our results suggest that infected immunocompromised individuals may play a significant role in the antigenic evolution of SARS-CoV-2, we urge caution in how this message is interpreted and communicated. While our model is informative, it does not capture the true complexity of antigenic space, the impact of vaccinations and non-pharmaceutical interventions, 
medRxiv preprint doi: https://doi.org/10.1101/2022.01.13.22269154; this version posted January 13, 2022. The copyright holder for this preprint (which was not certified by peer review) is the author/funder, who has granted medRxiv a license to display the preprint in perpetuity.

It is made available under a CC-BY-ND 4.0 International license .

317 variation in disease outcomes, and the evolution of other disease characteristics such as

318 transmissibility and virulence. This is by design so that our model requires as few assumptions as

319 possible. We did not attempt to capture these effects, as our results are intended to be illustrative of

320 the key roles that epistasis and immunocompromised individuals may play in the antigenic evolution

321 of SARS-CoV-2 (and other pathogens). We urge particular caution with regards to the implications of

322 our results for people who are immunocompromised. People may be immunocompromised for a

323 variety of reasons, including uncontrolled HIV, undergoing treatment for cancer, or as a transplant

324 recipient, and some conditions still wrongly attract stigma. Although Omicron was first detected in

325 South Africa, which is estimated to have the highest HIV prevalence in the world ( 7.7 million people,

326 with many infections uncontrolled [38]), this variant may have evolved in an individual without HIV

327 and may have evolved elsewhere. Rather than stigmatising people who are immunocompromised,

328 our results emphasise the need for global health equality. Improving access to vaccines and

329 treatments, especially in lower- and middle-income countries, and facilitating wider surveillance for

330 new variants is crucial for controlling the COVID-19 pandemic.

\section{Appendix}

\section{Within-host model}

334 The model in the main text focuses on population-level dynamics and implicitly models within-host

dynamics by assuming that: (1) immunocompetent and immunocompromised hosts differ in terms

of their average infectious period; and (2) antigenic evolution occurs at a constant rate. Here, we consider the dynamics of a simple within-host model to justify the implicit within-host dynamics in our population-level model. 
340 Let $V_{i}$ be the viral abundance of variant $i \in\{1, \ldots, n\}$ within a single infected host and let $R_{i}$ be the 341 strength of the corresponding immune response. The virus grows exponentially with rate $r$ in the 342 absence of an immune response and decreases through the immune response at rate $\kappa \sum_{j=1}^{n} \tilde{\sigma}_{i j} R_{j}$, 343 where $\kappa$ is the per-capita rate of virus removal by the host immune system and $\tilde{\sigma}_{i j}$ is the probability that an immune response for variant $j$ causes cross-immunity to variant $i$ such that

$$
\tilde{\sigma}_{i j}=\exp \left\{-\frac{(i-j)^{2}}{2 \tilde{\eta}}\right\}
$$

where $\tilde{\eta}$ controls the breadth of cross-immunity between variants (similar to $\eta$ in the main text). The virus also mutates to adjacent variants in the antigenic space with rate $\tilde{\mu}$. The immune response to variant $i$ increases at per-capita rate $\kappa q V_{i}$ and decays with rate $d$. The parameter $q$ controls the strength of host immune system such that larger values indicate an immune system that can respond well to infection (immunocompetent) and smaller values indicate a weaker immune response (immunocompromised).

As with the between-host model, we use the stochastic $\tau$-leaping method [22] to simulate the within-host dynamics, corresponding to the following set of ODEs

$$
\begin{gathered}
\frac{d V_{i}}{d t}=r V_{i}-\kappa V_{i} \sum_{j=1}^{n} \tilde{\sigma}_{i j} R_{j}-\frac{\tilde{\mu} V_{i}}{1+\delta_{i}}+\frac{1}{2} \tilde{\mu} \widetilde{M}_{i} \\
\frac{d R_{i}}{d t}=\left(\kappa q V_{i}-d\right) R_{i}
\end{gathered}
$$

354 where $\widetilde{M}_{i}$ is the set of variants adjacent to $i$ in the one-dimensional antigenic space $\left(\widetilde{M}_{i}=V_{i-1}+\right.$ $355 V_{i+1}$ for $i \in\{2, \ldots, n-1\}$, with boundary conditions $\widetilde{M}_{1}=V_{2}$ and $\left.\widetilde{M}_{n}=V_{n-1}\right)$, and $\delta_{i}=1$ if $356 i \in\{1, n\}$ and is 0 otherwise to control the mutation rate at the boundaries. 
medRxiv preprint doi: https://doi.org/10.1101/2022.01.13.22269154; this version posted January 13, 2022. The copyright holder for this preprint (which was not certified by peer review) is the author/funder, who has granted medRxiv a license to display the preprint in perpetuity.

It is made available under a CC-BY-ND 4.0 International license .

When the host is immunocompetent (large ), the infection is rapidly cleared, with little within-host evolution (Fig. A1a). But when the host is immunocompromised (small ), the infection persists over much longer timescales, with immune pressure leading to successive selective sweeps as the virus diffuses through the antigenic space at a constant rate (Fig. A1b). If the mutation rate is faster in immunocompromised hosts (larger ), the coevolutionary dynamics of the virus and the immune response are accelerated but the rate of antigenic evolution remains constant (Fig. A1c). These results justify the simplifying assumptions in our population-level model regarding within-host

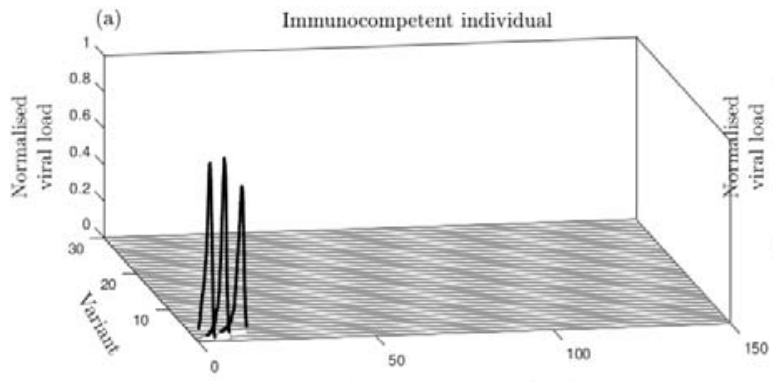

(b) Immunocompromised individual

Time since infection (days)
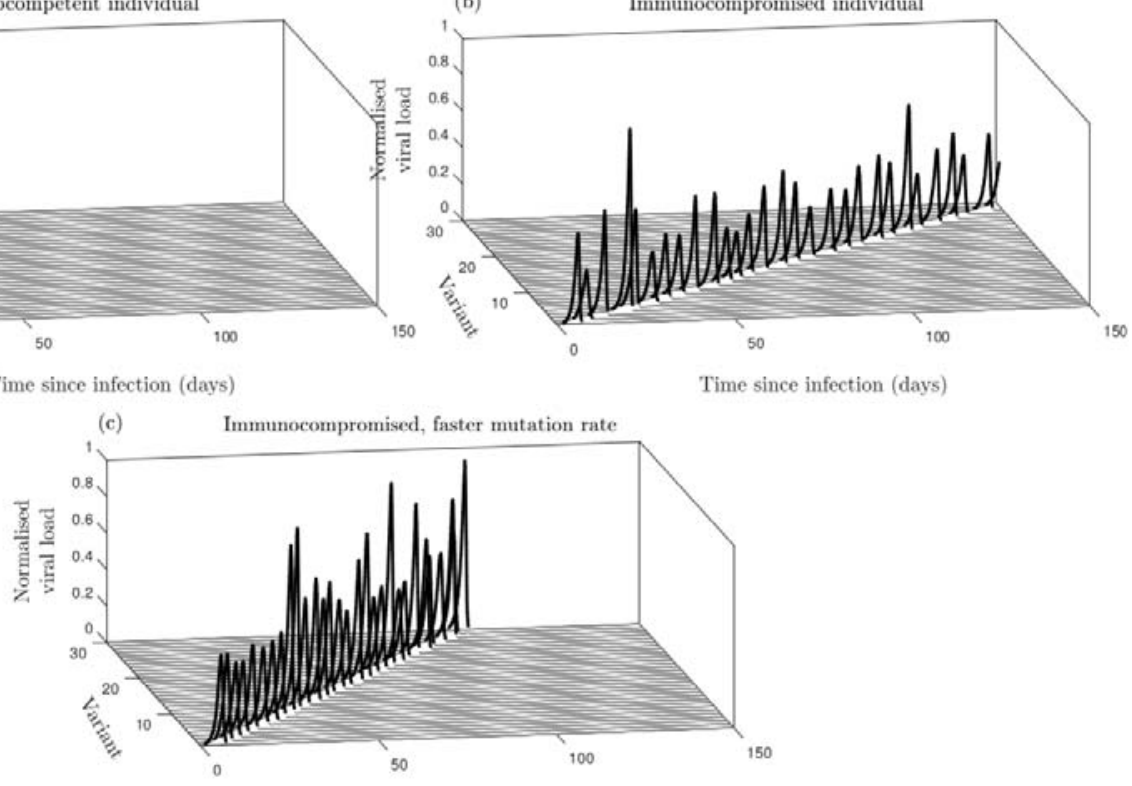

Time since infection (days) 
medRxiv preprint doi: https://doi.org/10.1101/2022.01.13.22269154; this version posted January 13, 2022. The copyright holder for this preprint (which was not certified by peer review) is the author/funder, who has granted medRxiv a license to display the preprint in perpetuity. It is made available under a CC-BY-ND 4.0 International license.

373 We simulate our within-host and population-level models using the $\tau$-leaping method [22], which is

374 an approximate stochastic simulation algorithm. We define the propensity functions $\alpha_{E}^{i}$ in Table A1,

375 which give the rates of event type $E$ for each variant index $i$. These propensity functions are then

376 used to update the system synchronously at a time interval of one day using random numbers from

377 the Poisson distribution $P\left(\alpha_{E}^{i}\right)$. Source code for the simulations is available in the Supplementary

378 Material and at:

379 https://github.com/ecoevotheory/Smith and Ashby 2022. 
medRxiv preprint doi: https://doi.org/10.1101/2022.01.13.22269154; this version posted January 13, 2022. The copyright holder for this preprint (which was not certified by peer review) is the author/funder, who has granted medRxiv a license to display the preprint in perpetuity. It is made available under a CC-BY-ND 4.0 International license .

\begin{tabular}{|c|c|}
\hline Event & Rate \\
\hline $\begin{array}{l}\text { Infection of host type } k \in\{H, C\} \\
\text { by variant } i\end{array}$ & $\alpha_{\mathrm{Inf}, k}^{i}=\beta_{i} S_{k}^{i}\left(I_{H}^{i}+I_{S}^{i}\right)$ \\
\hline $\begin{array}{l}\text { Gain of full immunity to variant } i \\
\text { due to infection by variant } j \text { (host } \\
\text { type } k \in\{H, C\} \text { ) }\end{array}$ & $\alpha_{\mathrm{Imm}, j, k}^{i}=\beta_{j} \sigma_{i j} S_{k}^{i}\left(I_{H}^{j}+I_{S}^{j}\right)$ \\
\hline $\begin{array}{l}\text { Recovery by host type } k \in\{H, C\} \\
\text { from variant } i\end{array}$ & $\alpha_{\mathrm{Rec}, k}^{i}=\gamma_{k} I_{k}^{i}$ \\
\hline $\begin{array}{l}\text { Mutation from variant } i \text { to variant } \\
i \pm 1 \text { for host type } k \in\{H, C\}\end{array}$ & $\alpha_{\mathrm{Mut}, k}^{i}=\frac{\mu_{k}}{1+\delta_{i}} I_{k}^{i}$ \\
\hline
\end{tabular}

\begin{tabular}{|c|c|}
\hline Event & Rate \\
\hline Growth of variant $i$ & $\alpha_{\text {Grow }}^{i}=r V_{i}$ \\
\hline $\begin{array}{l}\text { Removal of variant } i \text { by the } \\
\text { corresponding immune response }\end{array}$ & $\alpha_{\mathrm{Rem}}^{i}=\kappa V_{i} R_{i}$ \\
\hline $\begin{array}{l}\text { Removal of variant } i \text { by immune } \\
\text { response with index } j\end{array}$ & $\alpha_{\text {Cross-rem, } j}^{i}=\kappa \tilde{\sigma}_{i j} V_{i} R_{j}$ \\
\hline $\begin{array}{l}\text { Mutation from variant } i \text { to variant } \\
i \pm 1\end{array}$ & $\alpha_{\mathrm{Mut},}^{i}=\frac{\tilde{\mu}}{1+\delta_{i}} V_{i}$ \\
\hline $\begin{array}{l}\text { Decay of immune response for } \\
\text { variant } i\end{array}$ & $\alpha_{\mathrm{Dec}}^{i}=d R_{i}$ \\
\hline
\end{tabular}


medRxiv preprint doi: https://doi.org/10.1101/2022.01.13.22269154; this version posted January 13, 2022. The copyright holder for this preprint (which was not certified by peer review) is the author/funder, who has granted medRxiv a license to display the preprint in perpetuity. It is made available under a CC-BY-ND 4.0 International license .

\begin{tabular}{|c|c|c|}
\hline Parameter & Description & Value \\
\hline$p$ & $\begin{array}{l}\text { Proportion } \\
\text { immunocompromised }\end{array}$ & 0.05 \\
\hline $\bar{\xi}$ & $\begin{array}{l}\text { Strength of epistasis } \\
\text { (proportional reduction } \\
\text { in transmission) }\end{array}$ & 0.8 \\
\hline$N$ & Population size & $10^{7}$ \\
\hline$n$ & Number of variants & 30 \\
\hline$\mu_{k}$ & $\begin{array}{l}\text { Mutation rate for } \\
k \in\{H, C\}\end{array}$ & 0.01 \\
\hline$R_{0}$ & $\begin{array}{l}\text { Basic reproductive } \\
\text { number }\end{array}$ & 3.0 \\
\hline$\gamma_{H}$ & $\begin{array}{l}\text { Recovery rate } \\
\text { (immunocompetent) }\end{array}$ & $1 / 7$ \\
\hline$\gamma_{C}$ & $\begin{array}{l}\text { Recovery rate } \\
\text { (immunocompromised) }\end{array}$ & $1 / 140$ \\
\hline$t_{\max }$ & Final time (days) & 1460 \\
\hline$\eta$ & $\begin{array}{l}\text { Strength of cross- } \\
\text { immunity }\end{array}$ & 10.0 \\
\hline
\end{tabular}

384

\begin{tabular}{|c|l|l|}
\hline Parameter & Description & Value \\
\hline$n$ & Number of variants & 30 \\
\hline$\tilde{\mu}$ & Mutation rate & $5 \times 10^{-3}$ \\
\hline$r$ & Viral growth rate & 1.0 \\
\hline$\kappa$ & $\begin{array}{l}\text { Viral clearance rate by } \\
\text { immune response }\end{array}$ & $2 \times 10^{-2}$ \\
\hline$t_{\text {max }}$ & $\begin{array}{l}\text { Relative strength of host } \\
\text { immune system }\end{array}$ & 0.1 \\
\hline$d$ & Final time (days) & 150 \\
\hline$\tilde{\eta}$ & $\begin{array}{l}\text { Decay rate of immune } \\
\text { response }\end{array}$ & $10^{-4}$ \\
\hline Table A4: Default parameters for the within-host model. & $\begin{array}{l}\text { Strength of cross- } \\
\text { immunity }\end{array}$ & 0.1 \\
\hline
\end{tabular}


medRxiv preprint doi: https://doi.org/10.1101/2022.01.13.22269154; this version posted January 13, 2022. The copyright holder for this preprint

(which was not certified by peer review) is the author/funder, who has granted medRxiv a license to display the preprint in perpetuity.

It is made available under a CC-BY-ND 4.0 International license .

\section{Acknowledgements}

387 We thank Angus Buckling for helpful discussions. CAS is funded by the Natural Environment

388 Research Council (NE/V003909/1). BA is funded by the Natural Environment Research Council

389 (NE/N014979/1 and NE/V003909/1).

390

391 Author contributions

392 BA conceived the study, CAS carried out the analysis, and both co-authored the manuscript.

394 Data accessibility

395 Source code for the simulations is available in the Supplementary Material and at:

396 https://github.com/ecoevotheory/Smith and Ashby 2022

398 References

399 1. Davies NG, Abbott S, Barnard RC et al. Estimated transmissibility and impact of SARS-CoV-2

400 lineage B.1.1.7 in England. Science 2021;372, DOI: 10.1126/science.abg3055.

401 2. Hagen A. How Dangerous is the Delta Variant. American Society for Microbiology 2021.

402 3. SPI-M. SPI-M-O: Consensus Statement on COVID-19., 2021.

403 4. Nexstrain. Genomic epidemiology of novel coronavirus - Global subsampling. 2021.

404 5. Cele S, Gazy I, Jackson L et al. Escape of SARS-CoV-2 501Y.V2 from neutralization by convalescent

405 plasma. Nature 2021;593:142-6. 
medRxiv preprint doi: https://doi.org/10.1101/2022.01.13.22269154; this version posted January 13, 2022. The copyright holder for this preprint (which was not certified by peer review) is the author/funder, who has granted medRxiv a license to display the preprint in perpetuity.

It is made available under a CC-BY-ND 4.0 International license .

406 6. Ferguson N, Ghani A, Cori A et al. Report 49: Growth, Population Distribution and Immune Escape 407 of Omicron in England., 2021.

408 7. Cao Y, Wang J, Jian F et al. Omicron escapes the majority of existing SARS-CoV-2 neutralizing 409 antibodies. Nature 2021, DOI: 10.1038/d41586-021-03796-6.

410 8. Day T, Gandon S, Lion S et al. On the evolutionary epidemiology of SARS-CoV-2. Current Biology

$411 \quad$ 2020;30:R849-57.

412 9. Viana R, Moyo S, Amoako DG et al. Rapid epidemic expansion of the SARS-CoV-2 Omicron variant 413 in southern Africa. medRxiv 2021:2021.12.19.21268028.

414 10. Kupferschmidt K. Where did "weird" omicron come from? 2021.

415 11. Grenfell BT, Pybus OG, Gog JR et al. Unifying the Epidemiological and Evolutionary Dynamics of

416 Pathogens. Science 2004;303:327-32.

417 12. Saad-Roy CM, Morris SE, Metcalf CJE et al. Epidemiological and evolutionary considerations of

418 SARS-CoV-2 vaccine dosing regimes. Science 2021;372:363-70.

419 13. Ashby B, Thompson RN. Non-pharmaceutical interventions and the emergence of pathogen

420 variants. Medrxiv 2021, DOI: 10.1101/2021.05.27.21257938.

421 14. Ritchie H, Mathieu E, Rodés-Guirao L et al. Coronovirus Pandemic (COVID-19). Published online at

422 OurWorldInData.org 2007.

423 15. Andrews N, Stowe J, Kirsebom F et al. Effectiveness of COVID-19 vaccines against the Omicron

424 (B.1.1.529) variant of concern. medRxiv 2021:2021.12.14.21267615.

425 16. Marchi J, Lässig M, Walczak AM et al. Antigenic waves of virus-immune coevolution. Proceedings

426 of the National Academy of Sciences 2021;118:e2103398118.

427 17. Corey L, Beyrer C, Cohen MS et al. SARS-CoV-2 Variants in Patients with Immunosuppression.

428 New England Journal of Medicine 2021;385:562-6. 
medRxiv preprint doi: https://doi.org/10.1101/2022.01.13.22269154; this version posted January 13, 2022. The copyright holder for this preprint (which was not certified by peer review) is the author/funder, who has granted medRxiv a license to display the preprint in perpetuity.

It is made available under a CC-BY-ND 4.0 International license .

429 18. Borges V, Isidro J, Cunha M et al. Long-Term Evolution of SARS-CoV-2 in an Immunocompromised

430 Patient with Non-Hodgkin Lymphoma. mSphere 2021;6, DOI: 10.1128/msphere.00244-21.

431 19. Weigang S, Fuchs J, Zimmer G et al. Within-host evolution of SARS-CoV-2 in an

432 immunosuppressed COVID-19 patient as a source of immune escape variants. Nature

433 Communications 2021;12:6405.

434 20. Kemp SA, Collier DA, Datir RP et al. SARS-CoV-2 evolution during treatment of chronic infection.

$435 \quad$ Nature 2021;592:277-82.

436 21. Gog JR, Grenfell BT. Dynamics and Selection of Many-Strain Pathogens., 2002.

437 22. Gillespie DT. Approximate accelerated stochastic simulation of chemically reacting systems. The 438 Journal of Chemical Physics 2001;115:1716-33.

439 23. Sagulenko P, Puller V, Neher RA. TreeTime: Maximum-likelihood phylodynamic analysis. Virus

440 Evolution 2018;4, DOI: 10.1093/ve/vex042.

441 24. Hadfield J, Megill C, Bell SM et al. Nextstrain: real-time tracking of pathogen evolution.

442 Bioinformatics 2018;34:4121-3.

443 25. Khare S, Gurry C, Freitas Let al. GISAID's Role in Pandemic Response. China CDC Weekly

$444 \quad 2021 ; 3: 1049-51$.

445 26. Elbe S, Buckland-Merrett G. Data, disease and diplomacy: GISAID's innovative contribution to 446 global health. Global Challenges 2017;1:33-46.

447 27. Shu Y, McCauley J. GISAID: Global initiative on sharing all influenza data - from vision to reality.

448 Eurosurveillance 2017;22, DOI: 10.2807/1560-7917.ES.2017.22.13.30494.

449 28. Yu G. Using ggtree to Visualize Data on Tree-Like Structures. Current Protocols in Bioinformatics $450 \quad$ 2020;69, DOI: 10.1002/cpbi.96. 
medRxiv preprint doi: https://doi.org/10.1101/2022.01.13.22269154; this version posted January 13, 2022. The copyright holder for this preprint (which was not certified by peer review) is the author/funder, who has granted medRxiv a license to display the preprint in perpetuity.

It is made available under a CC-BY-ND 4.0 International license .

451 29. Yu G, Lam TT-Y, Zhu H et al. Two Methods for Mapping and Visualizing Associated Data on

452 Phylogeny Using Ggtree. Molecular Biology and Evolution 2018;35:3041-3.

453 30. Yu G, Smith DK, Zhu H et al. ggtree: an R package for visualization and annotation of phylogenetic

454 trees with their covariates and other associated data. Methods in Ecology and Evolution 2017;8:28-

45536.

456 31. Eden JS, Chisholm RH, Bull RA et al. Persistent infections in immunocompromised hosts are

457 rarely sources of new pathogen variants. Virus Evolution 2017;3, DOI: 10.1093/ve/vex018.

458 32. van Egeren D, Novokhodko A, Stoddard M et al. Controlling long-term SARS-CoV-2 infections is

459 important for slowing viral evolution. 2021, DOI: 10.1101/2021.04.10.21255251.

460 33. Kissler SM, Fauver JR, Mack C et al. Viral dynamics of acute SARS-CoV-2 infection and

461 applications to diagnostic and public health strategies. PLOS Biology 2021;19, DOI:

$462 \quad 10.1371 /$ journal.pbio.3001333.

34. Ashby B, Gupta S, Buckling A. Effects of epistasis on infectivity range during host-parasite

464 coevolution. Evolution 2014;68:2972-82.

465 35. Paterson S, Vogwill T, Buckling A et al. Antagonistic coevolution accelerates molecular evolution.

$466 \quad$ Nature 2010;464:275-8.

467 36. Hall AR, Scanlan PD, Buckling A. Bacteria-Phage Coevolution and the Emergence of Generalist

468 Pathogens. The American Naturalist 2011;177:44-53.

469 37. Meyer JR, Dobias DT, Weitz JS et al. Repeatability and Contingency in the Evolution of a Key

470 Innovation in Phage Lambda. Science 2012;335:428-32.

471 38. Mahy M, Marsh K, Sabin K et al. HIV estimates through 2018. AIDS 2019;33:S203-11. 